\title{
1980 年を迎えて
}

論 説

\section{環境問題とシステム科学・技術}

京都大学工学部教授 椹 木 義一

システム工学を専攻していた筆者がいつしか環境問 題に関心をもちはじめたのはもう10年も前のことであ る、種々の物理的あるいは技術的な現象ならびにプロ セスについてその数学モデルの作成あるいはこれによ る計算機シミュレーションの技術, 予測の技術さらに は最適化の技術等の方法論を専門としていた者によっ て大気の污染, 河川の水質污染, 振動, 騒音等はその 応用対象としてきわめて興味深いものであった。 幸い 文部省のこの方面に関する十分な理解が得られた結果, 大学人の間だけではあったが, この方面の研究はここ 10年の間に素晴しい発展をみせた。すなおち文部省の 科学研究費「特定研究」によるプロジェクト的研究組 織の結成とその参加者の熱心な研究意欲によってての 方面に打ける学問と技術は，世界においてトップレベ ルにあるものといって過言ではなかろう。というのは システム科学的方法論を専門とする者と, 従来からの 環境科学や環境工学に携ってさた専門家との緊密な融 合は, このプロジェクト研究で達成されたのである。 筆者は幸にしててのプロジェクト研究のお世話役をや らせていただいたてとをての上なくうれしく，また誇 りに感じている。こんなこともあってか, 現在, シス テム科学の世界に誇る殿堂である I IASA（国際応用 システム解析研究所）の中の“資源と環境”という一つ の研究分野の諮問委員として現在その職責を果してい る. この諮問委員は, アメリカ・ソ連・イギリス・フ ランス・ポーランド书よび日本からの8名のこの方面の 専門家から構成されているが, 年に 1 回IIASAにお いて, 環境問題に関してのシステムズ・アプローチについ I I A S A においてなされた研究成果を中心討論し, 今後のありかたについて I I ASA所長にアドバイスを与 える役目を果している．乙のような会合に出席するたび に思うことは，さすが日本は公害先進国であり，ての方 面の研究に対する要求の切実さから当然とはいえ, そ の先端を行っていることに意を強くする次第である.

上記の研究は, 大気の予測, 水質污染の予測等を主 体とする環境システムを物理的なシステムとしてとら
えた時の研究であるが, 最近わが国において, 㴞㴞と して台頭している環境問題に対する新しいシステム的 接近法があることに注目したい。それは何であるか。 従来の自然科学的分野における研究者に限定されるこ となく，人文社会科学者を含めた研究チームとして取 り上げるべき問題が真剣に議論されるようになってき たことである.すなおち, 従来の理・農・工・医の諸 学に加えるに, 経済・法律・人間行動学等を基調とす る学問体系を総合する文字通り学際的なアプローチが 必要視されるに至ったのである。そしてての中心的役 割を果たす方法論として, 噮境問題を志向したシステ ムズ・アプローチが台頭してきたのである、そして， いよいよ噮境問題は原点に㷌ったより核心をつくもの となりつつある。すなわち人間は, 何をもって幸福と するかという意識構造の究明, 科学技術の発展による 開発と自然環境の保全との間のトレード・オフの問題 さらには利害を異にする複数個の人間集団の合意形成 の問題など，その解決は非常に困難なものであるとは いえ, 環境問題の解決としては終局の目標としてとら えざるを得ないのである。

さて，乙のような観点にたって環境問題を考えると 環境問題はこれだけを人間生活から切り離して扱うこ とは不合理である。すなわち, 人間活動に伴って起る エネルギーの問題, 資源の問題, 食糧問題, 人口問題 さらには地域開発問題などの関連がますます強まるこ とであろう．そして終局にはこのような問題を総合的 に管理する国レベル，自治体レベルでの政策決定に結 びつくことも当然である.こうなるとシステムズ・ア プローチもいよい上政策形成へ向けての科学であり, 技術であることは明らかとなって来た。そこで，わ机 われシステム科学技術に関係する者は, 全てのその他 の学問分野の人達と充分なコミュニケーションをとる ベく，ある時は謙虚に，ある時は大胆にその交流をは からなければならない。新しい問題解決型の科学技術 としてのシステム科学技術の発展在祈念しつつ筆をお く次第である. 